\title{
Curvularia martyniicola, a new species of foliicolous hyphomycetes on Martynia annua from India
}

\section{Kumar $\mathbf{S}^{1}$ and Singh $\mathbf{R}^{2}$}

${ }^{1}$ Department of Forest Pathology, Kerala Forest Research Institute, Peechi 680653, Kerala, India.

${ }^{2}$ Centre of Advanced Study in Botany, Institute of Science, Banaras Hindu University, Varanasi 221005, U.P., India

Kumar S, Singh R 2018 - Curvularia martyniicola, a new species of foliicolous hyphomycetes on Martynia annua from India. Studies in Fungi 3(1), 27-33, Doi 10.5943/sif/3/1/4

\begin{abstract}
In the micromycofloristic survey of some dematiaceous hyphomycetes from the Terai region of Uttar Pradesh (India), an undescribed species (C. martyniicola) of anamorphic fungus Curvularia Boedijn was found on living leaves of Martynia annua (Martyniaceae). The novel fungus is described, illustrated and discussed in details. The present species is compared with earlier reported similar taxon, and is characterized by longer conidiophores and conidia with less septa. A key is provided to all the species of Curvularia recorded on Martyniaceae and Pedaliaceae. The details of nomenclatural novelties were deposited in MycoBank (www.MycoBank.org).
\end{abstract}

Key words - Curvularia - foliar disease - hyphomycetes - mycodiversity - taxonomy

\section{Introduction}

Martyniaceae is one of the families of flowering plants belong to order Lamiales. Earlier, this family was included in the Pedaliaceae in the Cronquist system (under the order Scrophulariales) but now it has been separated from the Pedaliaceae based on phylogenetic study. Some members of the family are commonly known as 'Devil's claw', 'Cat's claw' or 'Unicorn plant'. The family consists of five genera and sixteen species (Christenhusz \& Byng 2016). The family is restricted to the New World and found primarily in subtropical and warm temperate areas from the southern half of the United States southward through Central America to Uruguay and Argentina, including many of the islands of the West Indies. Regarding Pedaliaceae, commonly called Sesame family or Pedalia family, includes 13 genera and 75 species (Christenhusz \& Byng 2016). Both families are characterized by having mucilaginous hairs, which often give the stems and leaves a slimy or clammy feel, and often have fruits with hooks or horns.

Curvularia (Ascomycota, Pezizomycotina, Dothideomycetes, Pleosporales, Pleosporaceae), is an anamorphic fungal genera established by Boedijn (1933) with type species Curvularia lunata (Wakker) Boedijn. The teleomorph of the fungus is Cochliobolus lunatus Nelson \& Haasis 1964. The species of the genus was mostly recorded from tropical region but few were reported from temperate region as plant pathogen, epiphytes, endophytes or saprobes on plant material, the genus has received attention comprising several species from clinical specimens from immune compromised patients (da Cunha et al. 2013, Madrid et al. 2014). Also, some species of Curvularia are reported from air (Almaguer et al. 2013), freshwater (Verma et al. 2013), marine (Dai et al. 2010) and wetlands (Monteiro et al. 2003) ecosystems. 
After new phylogenetic refinements (Manamgoda et al. 2012, Tan et al. 2014) some species previously known as Bipolaris were also grouped in Curvularia according to molecular data. Therefore now there are also distoseptate conidia in the genus Curvularia.The genus was characterized by having geniculate conidiophores and distoseptate to euseptate, curved conidia with enlarged darkened median cell by which the genus can be easily differ from Drechslera and Bipolaris (having distoseptate conidia). Total 155 records were available in indexfungorum (www.indexfungorum.org; retrieved 21 February 2018).

In 2014, this fungus was collected on living leaves of Martynia annua L. (Martyniaceae) during the investigations of microfungi associated with foliar disease of plant in the Terai region (subtropical region) of Uttar Pradesh (India). It showed remarkable differences from previously described Curvularia sp. and is therefore described here as new.

\section{Materials \& Methods}

In the continuation of characterization and exploration of foliar disease of plants from Terai region of Uttar Pradesh, India, the Martynia апnиa plant showing leaf blights were collected from Buddha Men's Hostel $\left(26^{\circ} 45^{\prime} 00.27^{\prime \prime} \mathrm{N}\right.$ and $\left.83^{\circ} 23^{\prime} 10.64^{\prime \prime} \mathrm{E}\right)$ of Gorakhpur University. The digital photographs of infection spots on host leaves were taken during the time of collection by using a Sony DSC-5730 camera. The samples were placed in separate zip-lock polyethylene bags and transported to the laboratory and processed by following the standard techniques (Castañeda-Ruiz 2005). The specimens for microscopic observation were prepared by hand sectioning and scraping, the slide preparations were mounted on clear lacto-phenol cotton blue mount mixture from infected areas of the leaves. Observations were made with an Olympus BX-51 light microscope by using the Syntek USB camera. The detailed observations and measurements of morphological characters were carried out at different magnification through a light microscope $(400 \times$ and $1000 \times)$. Morphotaxonomic determinations were made with the help of current literatures. The dried leaf specimen has been deposited in the Ajrekar Mycological Herbarium, (AMH, ARI), Pune. The taxonomic identifications were based on the literatures like Ellis (1971, 1976), Cannon \& Kirk (2007) and Seifert et al. (2011). The basis for the classification was the Kirk et al. (2008) system. This new findings were verified using the database of Index Fungorum (2018), Facesoffungi (Jayasiri et al. 2015) and Mycobank (2017).

\section{Results}

\section{Taxonomy}

Curvularia martyniicola Sham. Kumar \& Raghv. Singh, sp. nov.

Figs $1-6$

MycoBank MB823340; Facesoffungi number: FoF03859

Etymology: the specific epithet in reference to the host.

Anamorphic fungus, hyphomycetes, Phytopathogenic, Foliicolous, Infection spots initially hypogenous but later on amphigenous, circular, sub-circular to irregular, necrotic to blight, initially dark brown, but later blackish. Colonies effuse, grayish brown to dark brown. Mycelium internal. Sexual morph: undetermined. Asexual morph on leaves: Stromata absent. Conidiophores arising singly or in fasicles (2-4), cylindrical, erect to procumbent, geniculate, straight to flexuous, unbranched, smooth, thick-walled, 5-10-septate, mid brown, 95-200 × 5-7 $\mu \mathrm{m}$, basal cell swollen. Conidiogenous cells integrated, terminal, mono to polytretic, scars thickened. Conidia acrogenous, dry, solitary, simple, unbranched, thick-walled, smooth, straight to curved, ellipsoidal to curved, 23-septate, $25-45 \times 10-15 \mu \mathrm{m}(\mathrm{x}=35 \times 12.5 \mu \mathrm{m}, \mathrm{n}=15)$, rounded at both ends; with third cell larger than other cells, dark brown, hilum thickened $(1.5-2 \mu \mathrm{m})$ and protuberant.

Teleomorph - not observed.

Known distribution - India (in this paper) 
Material examined - INDIA, Uttar Pradesh, Gorakhpur, Buddha Men's Hostel, Gorakhpur University Campus, on living leaves of Martynia annua L. (Martyniaceae), $7^{\text {th }}$ October, 2014, Coll., Shambhu Kumar, AMH-9701 (holotype), BSIPMH-045 (isotype).

Notes - There was no any record of Curvularia on host and family (Farr \& Rossman 2018) but C. eragrostidis (Henn.) J.A. Meyer (1959) has reported on previously placed family Pedaliaceae. Therefore, the present collection is comparable with C. eragrostidis. (Table 1)

Based on comparison it is clear that the conidiophores of $C$. martyniicola are longer and have more septa (95-200 $\times 5-7 \mu \mathrm{m}, 5-10$-septate) than $C$. eragrostidis (75-85× 5-7 $\mu \mathrm{m}, 5-6$-septate). The conidia of $C$. martyniicola are longer $(25-45 \times 10-15 \mu \mathrm{m})$, less septate $(2-3)$ and slightly straight to curved as compared to $C$. eragrostidis $(22-33 \times 10-18 \mu \mathrm{m}, 3$-septate). Therefore, the present collection is treated as new species.

Table 1 Comparison of $C$. martyniicola with similar sp.

\begin{tabular}{llll}
\hline Curvularia spp. & Conidiophores & Conidia & Host \\
\hline C. eragrostidis & $\begin{array}{lll}75-85 \times 5-7 \mu \mathrm{m}, \\
5-6-\mathrm{septate}\end{array}$ & $\begin{array}{l}22-33 \times 10-18 \mu \mathrm{m}, \\
3 \text {-septate, straight }\end{array}$ & Sesamum \\
& $\begin{array}{l}25-45 \times 10-15 \mu \mathrm{m}, \\
\text { C. martyniicola }\end{array}$ & $\begin{array}{l}\text { 2-3-septate, } \\
\text { slightly straight } \\
\text { to curved }\end{array}$ & Martynia \\
& & & \\
& &
\end{tabular}

Key of all Curvularia spp. reported on Martyniaceae and Pedaliaceae

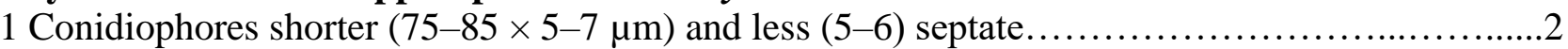

$1 *$ Conidiophore longer $(95-200 \times 5-7 \mu \mathrm{m})$ and more $(5-10)$ septate............................

2 Conidia smaller $(22-33 \times 10-18 \mu \mathrm{m}), 3$-septate and straight......................... eragrostidis

3 Conidia longer $(25-45 \times 10-15 \mu \mathrm{m}), 2-3$-septate and slightly straight to curved...C. martyniicola 



Figs 1-3 - Curvularia martyniicola on Martynia annua L. (AMH 9701, holotype). 1 Host plant. 2 Early stage of infection on leaf. 3 Late stage of infection on leaf. Scale bars: $2-3=20 \mathrm{~mm}$. 


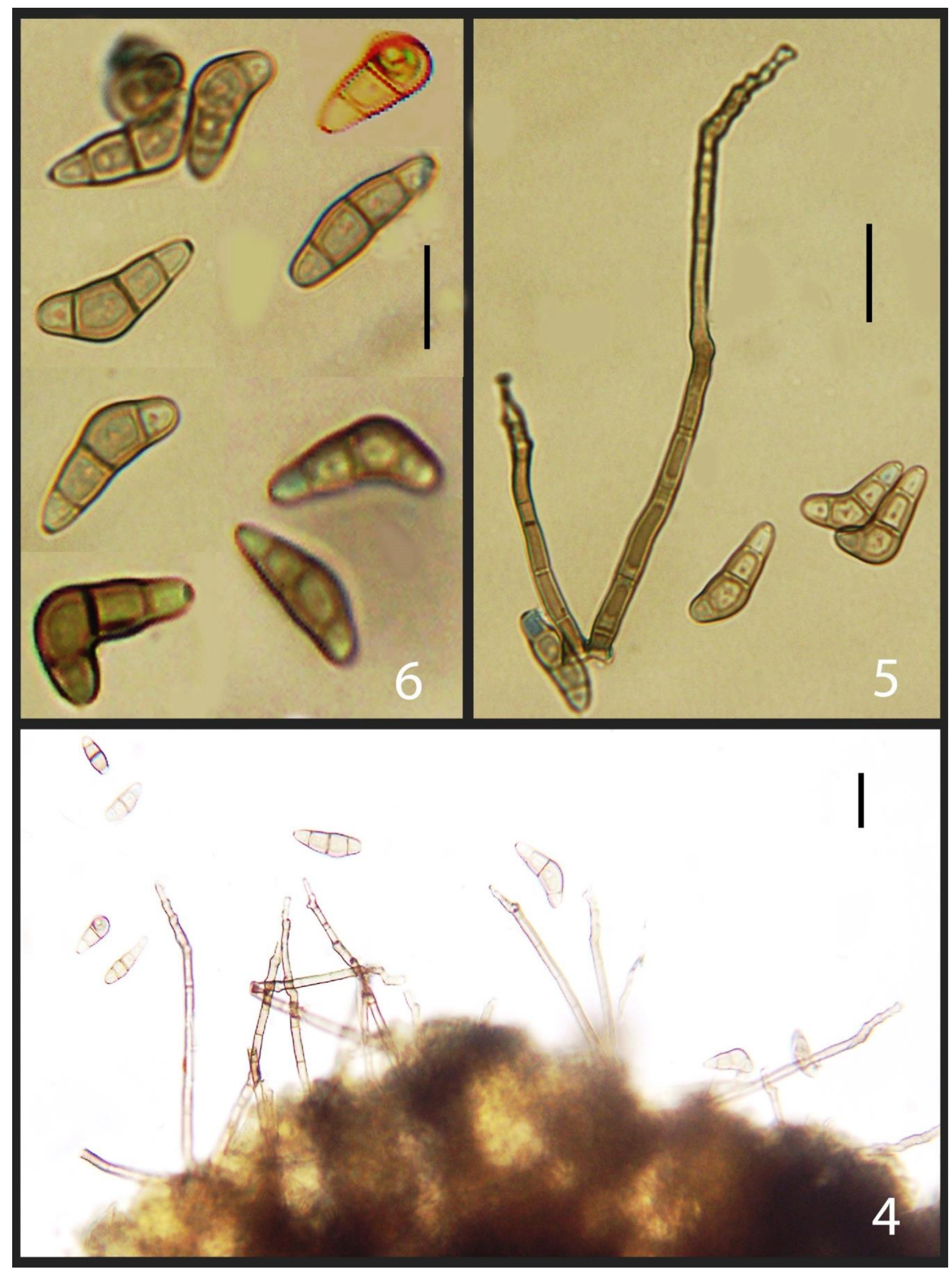

Figs 4-6 - Curvularia martyniicola, microphotographs (AMH 9701, holotype). 4 Conidiophores in fascicle. 5 Conidiophores with conidia. 6 Conidia. Scale bars: 4-6=20 $\mu \mathrm{m}$. 


\section{Acknowledgements}

We express our gratitude to the Director, Kerala Forest Research Institute, Peechi, Kerala for necessary facilities. We are thankful to the Anonymous reviewer for their constructive review with criticism on the manuscript. Thanks are also due to the Curator, Ajrekar Mycological Herbarium $(\mathrm{AMH})$, Agharkar Research Institute, Pune for providing accession numbers. Financial assistance (SB/YS/LS-288/2013) to the first author (SK) provided by the SERB, DST, Govt. of India is very much acknowledged.

\section{References}

Almaguer M, Rojas TI, Dobal V, Batista A, Aira MJ. 2013 - Effect of temperature on growth and germination of conidia in Curvularia and Bipolaris species isolated from the air. Aerobiologia 29 (1), 13-20.

Boedijn KB. 1933 - Über einige phragmosporen Dematiazen. Bulletin du Jardin Botanique de Buitenzorg. 13, 120-134.

Cannon PF, Kirk PF. 2007 - Fungal Families of the World. Wallingford, UK: CAB International. pp 456.

Castañeda-Ruiz R. 2005 - Metodología en el estudio de los hongos anamorfos. In: Anais do V Congresso Latino Americano de Micologia, Brasília, pp 182-183.

Christenhusz MJM, Byng JW. 2016 - The number of known plants species in the world and its annual increase. Phytotaxa 261, 201-217.

da Cunha KC, Sutton DA, Fothergill AW, Gené J et al. 2013 - In vitro antifungal susceptibility and molecular identity of 99 clinical isolates of the opportunistic fungal genus Curvularia. Diagnostic microbiology and infectious disease 76, 168-174.

Dai J, Krohn K, Flörke U, Pescitelli G et al. 2010 - Curvularin-Type Metabolites from the Fungus Curvularia sp. Isolated from a Marine Alga. European Journal of Organic Chemistry 2010, 6928-6937.

Ellis MB. 1971 - Dematiaceous Hyphomycetes, Commonwealth Mycological Institute, Kew, England. pp 608.

Ellis MB. 1976 - More Dematiaceous Hyphomycetes, Commonwealth Mycological Institute, Kew, England. pp 507.

Farr DF, Rossman AY. 2018 - Fungal Databases, Systematic Mycology and Microbiology Laboratory, ARS, USDA, retrieved February 21, 2018, from http://nt.arsgrin.gov/fungaldatabases/

Indexfungorum. 2018 - www.indexfungorum.org; retrieved 21 February 2018.

Jayasiri SC, Hyde KD, Ariyawansa HA, Bhat J et al. 2015 - The Faces of Fungi database: fungal names linked with morphology, phylogeny and human impacts. Fungal Diversity 74, 3-18.

Kirk PF, Cannon PF, Minter DW, Stalpers JA. 2008 - Dictionary of the Fungi. 10th ed. Wallingford, UK: CAB International. pp 784.

Seifert KA, Morgan-Jones G, Gams W, Kendrick B. 2011 - The genera of Hyphomycetes. CBSKNAW Fungal Biodiversity Centre Utrecht, the Netherland.

MycoBank. 2017 - MycoBank (Fungal databases nomenclature and species banks). www.mycobank.org, accessed 30 October 2017.

Meyer JA. 1959 - Moisissures du sol et des litières de la région de Yangambi (Congo Belge). Publications de l'Institut Agronomique du Congo Belge. 75, 1-211.

Madrid H, da Cunha KC, Gené J, Dijksterhuis J et al. 2014 - Novel Curvularia species from clinical specimens. Persoonia 33, 48-60. http://dx.doi.org/10.3767/003158514X683538

Manamgoda DS, Cai L, McKenzie EHC, Crous PW et al. 2012 - A phylogenetic and taxonomic re-evaluation of the Bipolaris-Cochliobolus-Curvularia complex. Fungal Diversity 56, 131144.

Monteiro FT, Vieira BS, Barreto RW. 2003 - Curvularia lunata and Phyllachora sp.: two fungal pathogens of the grassy weed Hymenachne amplexicaulis from Brazil. Australasian Plant Pathology 32, 449-453. 
Tan YP, Madrid H, Crous PW, Shivas RG. 2014 - Johnalcornia gen. et. comb. nov., and nine new combinations in Curvularia based on molecular phylogenetic analysis. Australasian Plant Pathology 43: 589-603.

Verma P, Singh S, Singh R. 2013 - Seven species of Curvularia isolated from three lakes of Bhopal. Advances in Life Science and Technology 8, 13-15. 